\title{
Pass-Through of Crude-oil Price Shocks to Consumer Prices in Nigeria: Pre and Post 2008 Global Financial Crisis
}

\section{Eric I. Otoakhia ${ }^{1}$}

This study investigates the responses of consumer price index (CPI) to crude oil price shocks in the pre-and post-2008 global financial crisis. The study used the Structural Vector Autoregressive model to analyse monthly data from 2000M01 to 2019M12. The impulse response analysis showed that for pre and post-crisis periods, oil price shocks have a positive impact on CPI. This impact was an insignificant direct momentary increase in pre-crisis CPI before dissipating. Conversely, the impact on post crisis CPI response tends to be stable and long-lasting starting from the third month. The confidence bands for the post crisis CPI are large, indicating the longlasting positive response in the CPI pose no significant threat to price stability in the long run horizon. In conclusion, CPI response varies in terms of intensity for pre and post crisis periods. In terms of level of significance, the effect of the shocks on CPI is transient and insignificant in both periods. The post crisis oil price shock is not a significant channel that created price instability in Nigeria after the crisis and this study recommend partial deregulation of energy price should be maintained. Establishing oil price -inflation pass-through, external shocks like financial crisis should be accounted for.

Keywords: Consumer price index, financial crisis, oil price, post crisis, structural vector autoregressive

JEL Classification: C32, F31, E31, Q43

DOI: $10.33429 /$ Cjas. $11220.5 / 8$

\section{Introduction}

The 2008 Global Financial Crisis (GFC) which originated from the United State of America is termed as the worst financial crisis after the Great Depression of the 1930s. This crisis spilled to other developed, emerging and developing economies due to the interdependency among the world economies. During the crisis, financial sectors in the developed, emerging and developing economies were the hardest hit due to their inability to absorb the shock posed by the crisis, prompting monetary authorities to enhance their liquidity ratio and increase

\footnotetext{
${ }^{1}$ Graduated from Department of Economics and Statistics, University of Benin, Benin City. Email: otoakhiai@gmail.com Phone: 08188869001.

I am grateful for the useful comments and suggestions made by Attahir B. Abubakar, Department of Economics, Business School, Ahmadu Bello University, Zaria - Nigeria.
} 
money supply just to stem the crisis.

Prior to the GFC, crude oil price was fast increasing. Conversely, the post-crisis period as Chen and Cao (2019) described is characterised by uncertainty in global oil prices. The heightened risk leads to lower consumer prices and heightened future expectation on domestic prices (Leduc \& and Liu, 2012; Trehan \& Zorrilla, 2012). For an oil exporting country, such heightened risk further creates instability in foreign reserves accumulation.

The GFC is a major source of structural instabilities in almost all countries exposed to globalisation. Establishing oil price - inflation relationship can be difficult giving structural changes in an economy. In addition, in a deregulated economy like Nigeria, fuel subsidy is another factor that can also thwart the relationship. This has been established by Brini et al. (2016) and Choi et al. (2017). The facts that surrounds energy subsidies in Nigeria entails much ambiguities. Improvement in oil revenues for the government in midst of increasing oil price enhanced social and political support for energy subsidy. The revise is the case when oil prices declined continuously then accompanied by decreasing government revenues.

Structural instabilities can also emerge due to abrupt policy change. Across the two episodes (pre and post crisis eras), varying policies on energy prices surfaced. Fuel subsidy has been partially removed 6 times in the pre-crisis era, while the post crisis period witnessed partial and abrupt removal and reintroduction between 2012 and 2016. Subsequently, the price modulation framework has replaced the subsidy regime. This came at a critical time when oil price is crashing.

The apparent differences among the episodes create a motivating point for examining the oil price - inflation relationship prior and post crisis eras. An existing study of pre- and post2008 crisis oil price - inflation relationship is Adekoya and Adebiyi (2020) for Economic Co-operation and Development (OECD) countries. Prior to the crisis, Olomola and Adejumo (2006) examined the response of domestic price level to oil price and observed it has no substantial effect on CPI in Nigeria. The studies by Demachi (2012); Adenuga et al. (2012); Asekunowo (2016) and Omolade, Nwosa, and Ngalawa, (2019), form part of the existing studies in Nigeria, but did not consider the responses to oil price shock in the two eras. These studies thus derived varying responses of CPI to oil price shocks. For instance, findings from Demachi (2012) and Omolade et al. (2019) show that oil price did not pose a grave concern 
to domestic price level. On the contrary, studies by Adenuga et al. (2012) and Bala and Chin (2018) show oil price did affect consumer price index. The oil price-inflation relationship still remains a contentious issue in the literature.

This study attempts to contribute to the debate on the dynamic pass-through of crude oil price shocks to the Consumer price index - core inflation in the pre- and post-2008 crisis. Since the pre-crisis era witnessed gradual removal and the post crisis period witnessed greater instability and complete removal of subsidy, the oil price pass-through to inflation could take a different dimension. Specifically, this study seeks to examine if the responses of consumer price index to shock in crude oil price varies in the pre-crisis and post crisis era. Based on the literature conducted on Nigeria, this work appears to be the first country specific study to investigate the responses of consumer price index across the eras. This is expected to shed light on the dynamics of domestic price across the periods after accounting for external shocks on the economy. The crisis posed significant structural instability in the domestic economy given its reliance on oil price which is traded internationally.

This study adopted theoretical restrictions to identify the SVAR deployed on monthly data from February 2000 to December 2019. The novelty of this study is that it investigates the changing pattern of oil price pass-through to domestic prices by splitting the sample which enables varying the inflationary elasticities based on the 2008 global financial crisis. This study is essential in understanding the changes that accompany increasing volatility in the price of a product that serves as a lifeline for Nigeria.

The rest of this article is organised as follows: Section 2 reviewed the existing theoretical and empirical literature along with stylised facts. This is followed by Section 3, which presents discussion on the study data, model specification and estimation procedure. Next is Section 4, which is results and discussion. Finally, in Section 5, we conclude and present policy recommendations.

\section{Literature Review}

\subsection{Theoretical literature}

Theoretically, changes in oil prices in an oil importing country, is bound to affect consumer prices. This will have a ripple effect on consumption and thus, affect aggregate demand. From an oil exporting country, this effect will lead to changes in government revenue and the 
appreciation/depreciation of exchange rate via changes in external reserves. In addition, oil prices are indeed very volatile. A further effect of this volatility is the increase in uncertainties ascribed to frequent changes in oil prices in the international market. This hampers both foreign and domestic investor confidence.

Changes in oil prices are due to two factors. The demand-pull and the supply-push factors. The changes in oil prices due to increase in demand are said to bring about wealth transfer effect in oil exporting economies and inflation effect in oil importing economies. Whereas, changes in oil prices due to positive changes in supply of the commodity translate to supply side shock effects. Tang et al. (2010) classified all the transmission channels into six: output effect; wealth transfer effect; inflation effect; real balance effect; sector adjustment effect and unexpected effect. These channels have been the centre of attraction in modern times and this study focused on the inflation effect.

The wealth/income effect and real balance effect have been studied extensively. Famous among them is Krugman (1983) which illustrates the role of oil demand elasticities, the share of a country's export and import from oil-producing countries as factors that influenced exchange rate appreciation or depreciation. An increase in oil price leads to improvement in the current account balance of oil-exporting countries. Based on the wealth effect channel, when oil prices rise, wealth is transferred to oil-exporting countries (in US dollar terms) and is reflected as an improvement in exports and the current account balance in domestic currency terms (Beckmann, Czudaj \& Arora, 2017). This leads to an appreciation of the domestic currency of oil-exporting countries, while causing exchange rate depreciation in oil-importing countries in the short-run if the oil-importing country faces a current account deficit. In the long-run, the exchange rate of oil-importing countries appreciates when oilexporting countries invest the petrodollar in foreign-denominated assets of non-oil producing countries.

The use of energy permeates the nooks and cranny in an economy. Hence, changes in its prices are bound to affect the cost of production creating pressure on current and future price level. This gives rise to oil price - inflation effect. Bhattacharya and Bhattacharyya (2001) dissect the impact of oil price on inflation two phases. In the first phase, oil price shock automatically creates inflation effects due to hoarding of commodities. This phase holds when oil price shock creates inflation uncertainty. In phase two, the oil price increases the 
cost of production thereby creating the cost push effect.

The monetarist view of inflation is premised on the growth of money in circulation in relation to output growth. This view believes changes in money supply while output is constant translates to changes in domestic price level while the proportional change in the money supply and output do not cause inflation. This theory has gained wide application in developed and developing economies. The relevance of the monetarist view of inflation has been questioned in developing countries. The structuralist are of the opinion, for developing economies, structural rigidities explain inflation not just money supply growth.

The Structuralist believed factors that affects inflation in developing countries are the imbalances in agricultural development, presence of fiscal budget constraint and foreign exchange depletion. From these angles, inflation may not be fully linked to money supply but by the poor performance of agricultural output, poor taxation and fluctuation in export prices and external reserves volatility. In these cases, for a monoproduct economy like Nigeria, oil price movement does create imbalances on fiscal budget and optimal external reserves.

\subsection{Empirical Literature}

The reviewed literature includes cross-sectional studies in emerging and developing countries, which examined the pass-through effect of oil price on consumer price index. Findings from such studies have shown varying levels of intensity among the economies. These studies include Raghavan (2015) whose findings showed that oil price shocks have tremendous effect on consumer prices, whereas, Olomola and Adejumo (2006); Omolade, Ngalawa, and Kutu (2019) studies showed the shock is insignificant. On the contrary, for OPEC member countries in Africa, changes in oil prices increase the price level (Bala \& Chin, 2018). Similarly, Studies in more advanced economies and emerging economies (Blanchard \& Gali 2007; Lee $\&$ Song 2009) differ in the intensity of CPI response in pre- and post-crisis periods.

Among the early studies of oil price shock in Nigeria,Olomola and Adejumo (2006) adopted a SVAR model to examine the effect of oil price on key macroeconomic indicators which included inflation and exchange rate in Nigeria using quarterly data from 1970 to 2003. Their finding showed shock on oil price had no significant effect on domestic price level in the Nigeria economy. In addition, positive shock on real oil price leads to real exchange rate appreciation. 
Adenuga et al. (2012) used ARDL model to examine oil price pass-through to inflation in Nigeria. The findings showed that changes in oil price and exchange rate affect consumer price index significantly. Similarly, Asekunowo (2016) adopted a similar model and observed consumer price index is greatly affected by exchange rate and not crude oil price.

Akinleye and Ekpo, (2013) examine the symmetric and asymmetric effect of oil price and oil revenue shocks in Nigeria using quarterly data from 1970Q1 to 2010Q4. The authors' findings from the symmetric oil price shock in the unrestricted VAR indicated that shock on crude oil price has no inflationary pressure in the short-run. The shock leads to a depreciation of the exchange rate and a positive and insignificant impact on external reserves. The asymmetric shock on oil prices only differed for external reserves response. The finding showed the shock consistently depleted the reserves up to 9 quarters.

Demachi (2012) adopted SVAR and examine the effect of oil price and volatility on the macroeconomy in Nigeria using data from 1970M1 - 2011M5. The author concluded that oil price shock lead to exchange rate appreciation in Nigeria. Also, domestic price level did not respond significantly to oil price shock. Apere and Eniekezimene (2016) analysed crude oil price fluctuation in the Nigeria economy from 1981 to 2013 using SVAR. Their findings showed that exchange rate appreciated in the short run and tends to depreciate starting from seventh horizon as a result of crude oil price shock. Omolade, Nwosa, and Ngalawa, (2019) adopted SVAR to examine the monetary transmission channel of oil price shock in Nigeria. Their findings showed that crude oil price shocks lead to exchange rate appreciation in the long-run. The consumer price index response to the shock was negative and insignificant. This implies, shock on crude oil prices is not inflationary.

Abubakar (2019) adopt TAR and MTAR to examine the asymmetry of oil price and exchange rate in Nigeria. The study data range from 1986M01 to 2018M06. The finding showed the absence of asymmetric cointegration between the official exchange rate and oil price. The author further examined the effect of shock in crude oil prices on exchange rate and external reserves. Results from SVAR showed the official exchange rate appreciates after the fourth month (period). A similar check for the real effective exchange rate had a mild depreciation, then, followed by stronger appreciation starting from the second horizon.

From country specific studies reviewed, Lee and Song (2009) examine oil price shock in 
South Korean economy. They acknowledge structural break in 1998-1999 and then use nonparametric regression and SVAR to accessed how oil price and macroeconomic indicators differed for pre- and post-currency crisis of 1997. First, they adopted Gaussian kernel regression and noted CPI response to oil price changes is less clear on its functional form to oil price changes. In the post-crisis period - 2000 to 2009, positive movement in oil price did not account for the rise in CPI. Second, their results from the restricted SVAR showed CPI dropped instantly for a positive shock on oil price in pre-crisis period (1987 - 1997) and then steadily increase throughout the horizon. CPI in post-crisis period increase, followed by lesser positive movement in the long run.

Study in the US economy include Gao, Kim and Saba (2014) who investigate the dynamic effect of oil price shock on US consumer prices from 1974 M1 to 2014 M7. Their findings showed varying response of CPI sub-indices to positive oil price shock for all item CPI. Crude oil price shock increase overall consumer price.

In Pakistan, Usman, Nawaz and Qayyum (2011) used Glosten, Jagannathan and Runkle (GJR) model to estimate the volatility of oil prices in Pakistan and then adopted VAR model to assess the impact of oil price volatility on Pakistani economy. Their finding showed oil price shock had long-lasting positive effect on CPI. In another study, Younas \& Khan (2018) examine the exogenous shocks impact on Pakistani economy. They applied Recursive VAR to analyse monthly data from 2001 to 2016 . Their findings showed oil price shock had short run inflationary tendencies in the economy. Also, oil price had no major effect on real effective exchange rate.

Maina (2015) who adopted SVAR model on quarterly data from 1991Q1 to 2014Q4 using SVAR for Kenyan economy. The study showed exchange rate depreciate due to Crude oil price shock. Also, there is no instantaneous rise in CPI in the first and second quarter due to shock in oil prices. Marginal rise in CPI subsequently stabilises after reaching its peak level in the seventh quarter.

Omolade et al. (2019) examine the influenced of crude oil prices on macroeconomic indicators in eight oil-exporting countries in Africa using annual data. They used Hamilton Index to estimate positive and negative asymmetric movement in oil prices and then assessed the effect of positive and negative shocks on key macroeconomic indicators. The results from 
panel VAR model showed positive shock on crude oil price leads to insignificant rise in inflation, and exchange rate appreciation throughout the horizon. Negative oil price shock causes inflation to increase at first and then falls. The negative shock on oil price leads to exchange rate depreciation.

From the reviewed cross sectional studies, Brini, Jemmali and Farroukh, (2016) examine six MENA countries (Tunisia, Morocco, Algeria, Bahrain, Saudi Arabia and Iran) oil price and inflation dynamics. They observed small adjustment in CPI in the study countries for shock on oil price due to price subsidies. Such shock affects real exchange rate in the long run for Tunisia and Morocco who are oil importers. The authors highlighted, inflationary pressure associated with shock on oil prices was absorbed by the existence of price subsidies in these countries. Thus, shock in oil price do not translate into higher domestic prices.

Member countries of OPEC were reviewed by Bala and Chin (2018). They examine asymmetric impact of crude oil price changes in OPEC member countries in Africa (Algeria, Angola, Libya and Nigeria) using dynamic ARDL on data from 1995 to 2014. The results showed oil prices increase inflation in Oil producing countries. From asymmetric role, positive and negative changes in oil prices increase consumer price index. This inflationary tendency is higher for negative changes in oil prices.

Similarly, Raghavan (2015) examine the nature of the effects of various oil shocks on Association for South East Asian Nations (ASEAN-5) economies (Thailand, Indonesia, Malaysia, Philippine, and Singapore) using monthly data from 2000 to 2013. Raghavan (2015) observed recent oil price shocks are demand driven. Also, the author results further showed oil specific demand shocks have tremendous impact on price level (excluding Malaysia) and appreciation of exchange rate among the ASEAN-5 economies except for Malaysia and Singapore. The researcher concluded monetary authorities can tighten policies targeting price stability without fear of stagnating growth because the shocks have less impact on growth.

Živkov, Đurašković and Slavica Manić (2019) adopted wavelet-based Markov switching model to examine oil price - CPI pass-through for some European countries. They observed weak direct impact of oil price movement on consumer price index. The impact gets stronger in the long run for majority of CEECs. Exchange rate only affects inflation when shock on oil price leads to exchange rate depreciation. 
One of oldest work on Oil price - inflation relationship that adopt break point is that of Blanchard and Gali (2007). They compared 1970s and 1990s macroeconomic performance of developed economies in response to oil price shocks. Hypothesizing positive shock to oil price is similar in both decades. The result obtained after identifying mid-1980's as breakpoint showed much stronger increase in CPI pre-1983 data given a 10 percent increase in oil price. This is unlike the much weaker increase in CPI post-1984 data.

Choi et al. (2017) study the impact of oil prices on domestic consumer price index in 72 advanced and developing economies from 1970 to 2015. Their findings showed 10 percent shock on oil prices leads to 0.4 percent increase in the consumer price index for 2 years. Understanding the transmission mechanism in recent time from 2000M01 to 2015M12 using monthly data for developed and developing countries, their findings showed pass through of global oil prices on domestic price is less precise for emerging economies. The response among developed and emerging economies differed. The authors noted transport and energy subsidies explain variation in cross country's response to global shock on oil prices.

A more recent study was done by Adekoya and Adebiyi (2020). First, they observed oil priceinflation relation is affected by global financial crisis greatly for developed and developing countries in the long run and short run respectively. The pre-crisis and post crisis period by the authors are arbitrary and range from 2000M01 - 2007M12 and 2009M01 - 2018M02 respectively. Their findings indicated strong link between oil price and CPI in the pre-crisis era and the post crisis period witnessed inconclusive relation despite CPI upward trend. Adekoya and Adebiyi, (2020) findings from linear ARDL model indicated, for pre-crisis era, oil priceinflation relation is significantly positive in long run for developing countries. The post crisis period, this relation is strong and insignificant.

Time series studies in specific countries like Pakistan and Kenya (Usman, Nawaz \& Qayyum 2011; and Younas \& Khan, 2018; Maina, 2015) were reviewed and observed the oil price shock had a positive effect on inflation but differed in its intensity and duration. Existing literature in Nigeria that examine the dynamic response include Demachi (2013); Akinleye and Ekpo, (2013) and Omolade et al., (2019) unanimously agreed shock on crude oil price do not pose significant threat to price instability. This study complements the existing studies with a focus on how consumer price index vary across two episodes- the pre-crisis and post- 
Pass-Through of Crude-oil Price Shocks to Consumer Prices in Nigeria: Pre and Post 2008 Global Financial Crisis

Otoakhia

crisis.

\subsection{Some Stylized Facts}

This section provides graphical illustrations of the study variables' trends and cyclical fluctuation over the years. Figure 1 illustrates the consumer price index trend versus movement in Nigeria reference crude oil price. Between 2000 and 2004, the movement of consumer price index is relatively increasing at slower pace and crude oil price in this period fluctuates around \$18 per barrel and \$35 Per barrel.

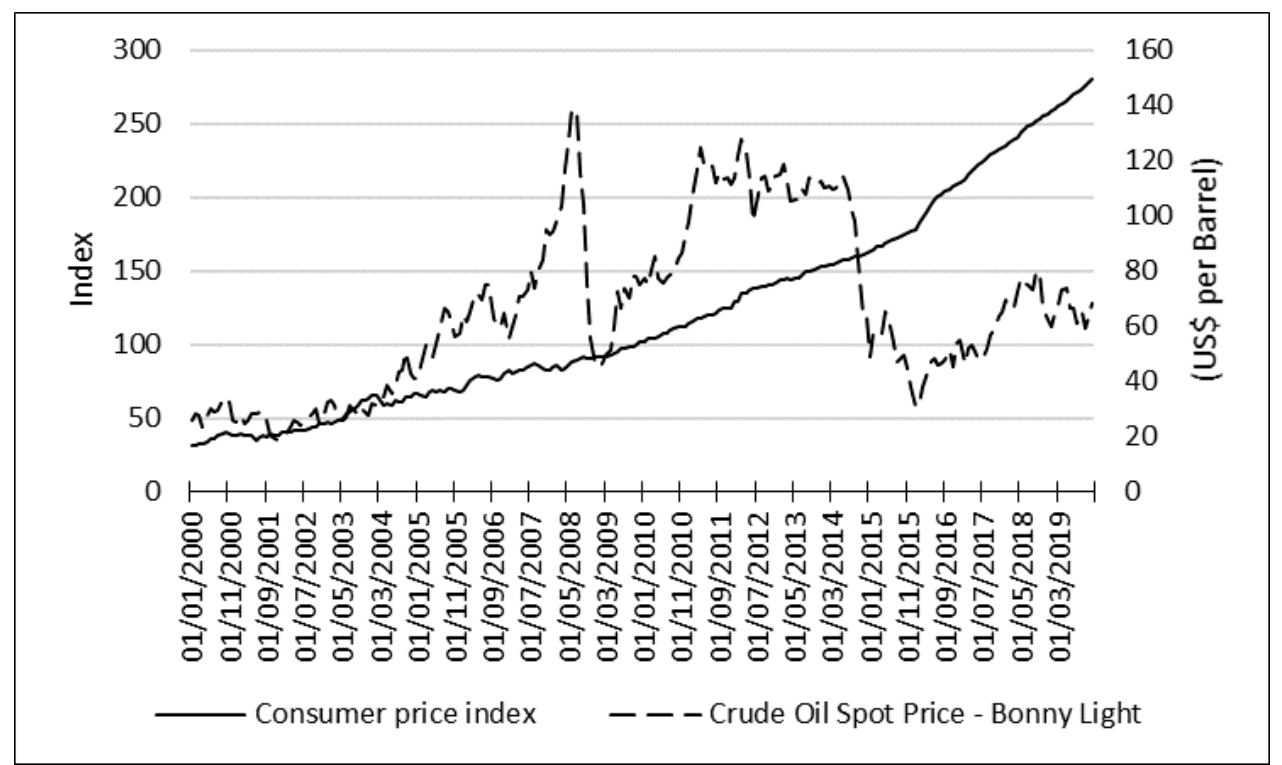

Figure 1: Crude oil price versus consumer price index

There was significant fluctuation in post-crisis movement in oil price compared to the precrisis period. The consumer price index became much steeper in the post crisis period (particularly from 2016) compared to the pre-crisis period. Figure 2 presents the relationship between crude oil price and external reserves in Nigeria. There is a positive relationship between external reserves and the referenced crude oil price. Higher crude oil price leads to reserves accretion. Nigeria's major export is crude oil and serves as the mainstay of the economy. About 82 percent of the total exports was made up of oil in 2018 (CBN, 2019). 


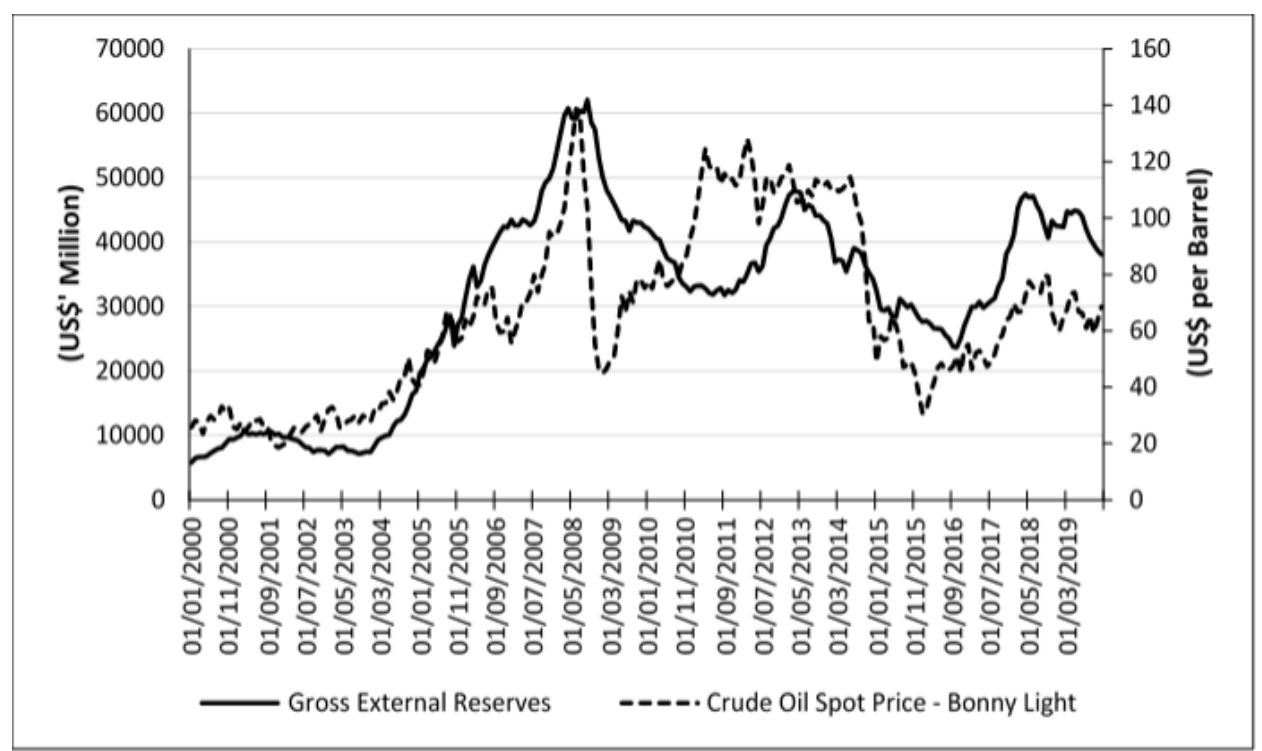

Figure 2: Crude oil price movement versus gross external reserves

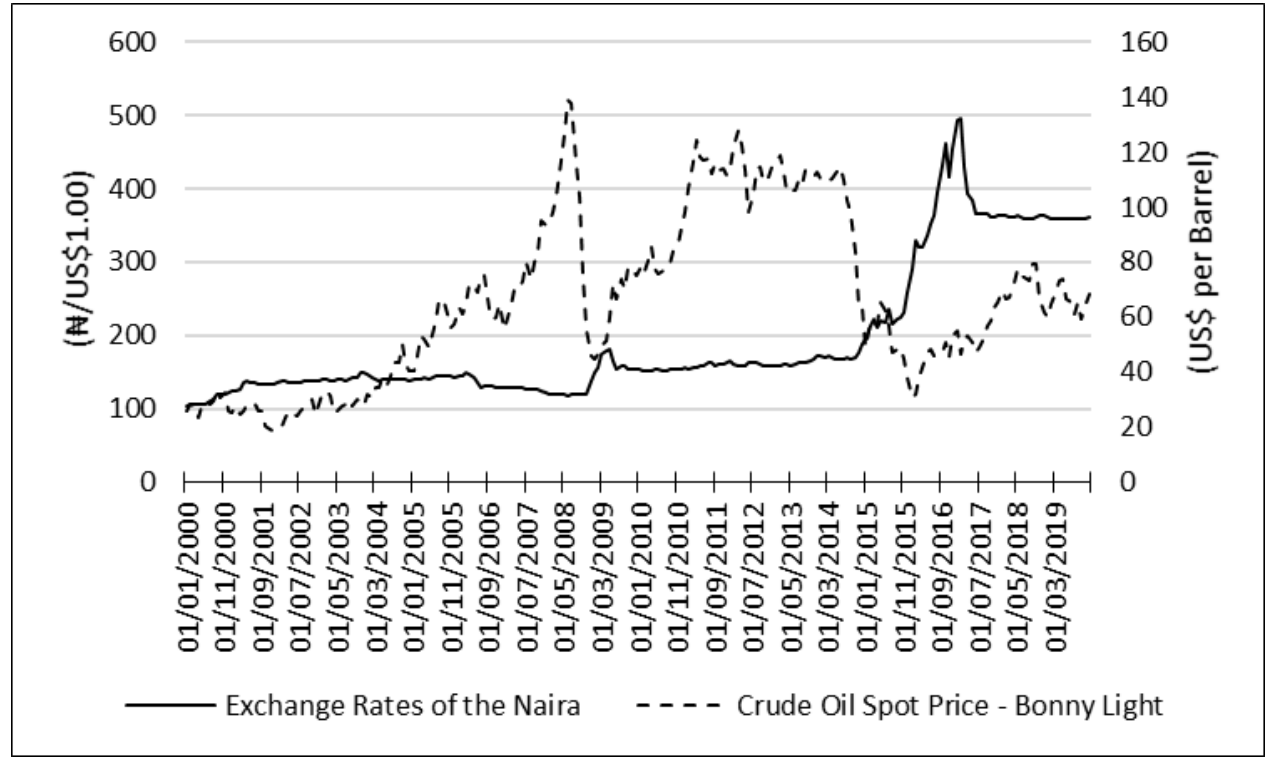

Figure 3: Crude oil price movement and BDC exchange rate

Figure 3 presents the relationship between exchange rate and crude oil prices. An upward movement of the exchange rate signifies devaluation/depreciation, while a downward trend indicates revaluation/appreciation. From 2006 to 2008, exchange rate appreciated amidst increasing oil price. Hence, pre-crisis exchange rate response is asymmetric to oil price upward trend prior to the global crisis. In the post crisis period, exchange rate depreciated consis- 
Pass-Through of Crude-oil Price Shocks to Consumer Prices in Nigeria: Pre and Post 2008 Global Financial Crisis

Otoakhia

tently as the oil price continued to soar randomly. This translates to reserve accretion during this period shown in Figure 2 given the monetary authority support in defending the domestic currency, thus leading to exchange rate appreciation. Sharp positive movement in exchange rate is recorded in December 2008 while oil price decreases significantly during the postcrisis period. The sudden upward trend witnessed in November 2008, 2014 and December 2015 and March, 2020 coincide with a consistent decrease in oil price.

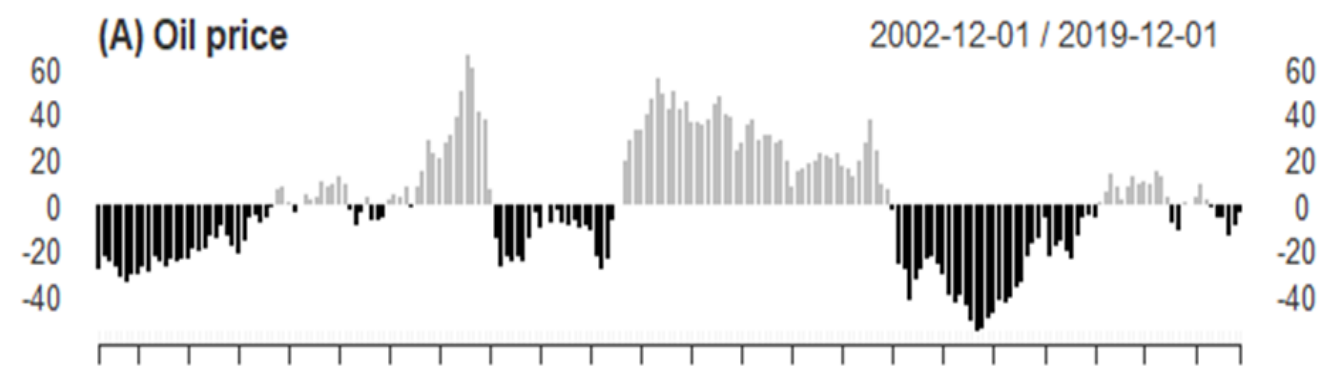

Dec 2002 Oct 2005 Jan 2008 Apr 2010 Jul 2012 Oct 2014 Jan 2017 Apr 2019

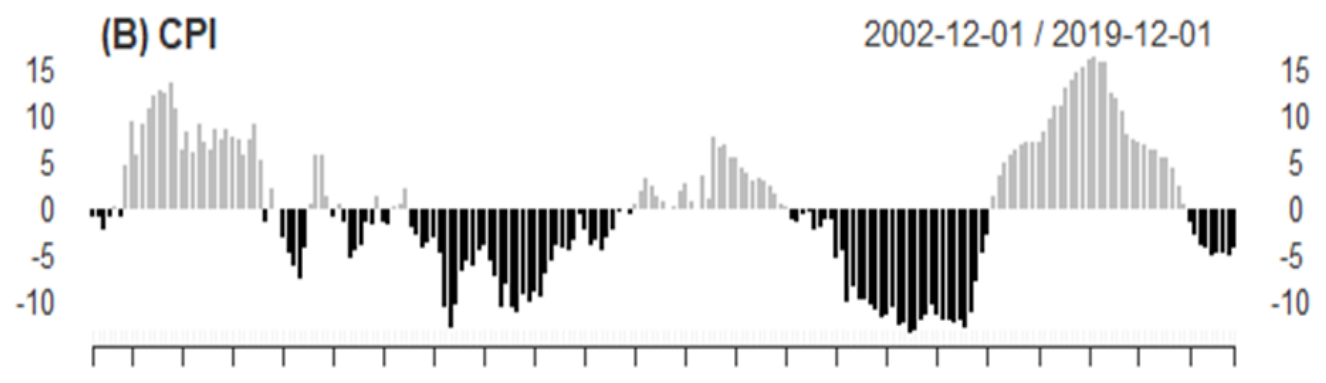

Dec 2002 Oct 2005 Jan 2008 Apr 2010 Jul 2012 Oct 2014 Jan 2017 Apr 2019

Figure 4: Oil price and consumer price index cyclical fluctuations

To gain some insight on the business cycle, in Figure 4, the Hamilton (2017) filter was adopted to check the cyclical movement among the variables. There is an inverse movement in crude oil price (COP) cyclical fluctuations and pre-crisis consumer price index (CPI). This inverse relationship in the pre-crisis period is positive between 2015 and 2016. Crude oil price and CPI are cohering during this period due to the internal shock on the economy. During this period, there were massive increase in domestic prices, devaluation of the domestic currency and consistent decrease in external reserves. The crude oil price in this period was the lowest in the post crisis period and then reverses after recovery. Between 2011 and 2012, 
tail end of Figure 4, there appears to be co-movement in their fluctuations. In times of economic crisis, cyclical fluctuation in the CPI and oil price have positive relation.

\section{Data and Methodology}

\subsection{Data}

This study adopts Monthly time series data from January 2000 to December 2019. The data were sourced from CBN quarterly statistical bulletin (2020Q1) and CBN statistical bulletin 2019. Consumer price index, crude oil price, exchange rate, prime lending (interest) rate and external reserves are in log difference form. In obtaining the data partition end-point for the pre-crisis episode, we adopt an arbitrary approach. Thus, the pre-crisis period partitioned from 2000M01 to 2008M05. The post crisis period started from July, 2009. The crisis period defined in this study is June, 2008 to June, 2009. During this defined period, exchange rate depreciated significantly by 16 percent - the highest within the study period. In addition, crude oil price during the crisis period had the highest deep of 27 percent. Fratzscher (2009) defined the crisis period from July 2008 to January 2009 for emerging markets. For OECD, Adekoya and Adebiyi (2020) defined the crisis period as January, 2008 to December, 2008. This study endpoint captures National Bureau of economic research (NBER) announcement of the end of the financial crisis in June, 2009. Furthermore, this study adopts NBER recession definition and the results presented in the appendix are compared with the study crisis period.

\subsection{Model Specification}

The study relied on the Structural Vector Auto regression (SVAR) model for the analysis of data. SVAR is often adopted in empirical analysis for prediction, assessing the effect of the structural shocks in a variable on another and gaining insight on the system forecast error decomposition. For theoretical purpose, a VAR with no constant is specified as

$$
A V_{t}=\beta_{i j} V_{t-j}+B \varepsilon_{i t}
$$

where $\mathrm{A}$ is a $n \times n$ matrix, $V_{t}$ is a $n \times 1$ vector of endogenous variables and $n$ is the number of variables in the VAR system. In this study, $n=4$ (crude oil price, consumer price index, exchange rate and external reserves). $\beta_{i j}$ is the $n \times n$ coefficient matrix of the lagged endogenous variables $V_{t-j}$ and $j$ is the lag order of the VAR. $B$ is an identity matrix of the error term, $\varepsilon_{i t}$. The error term is $n \times 1$ vector and has a white noise process. 
Equation 1 is over identified and cannot be estimated thus, the reduced form VAR is derived by multiplying both sides of equation 1 by the transpose of the inverse of matrix $\mathrm{A}, A^{-I}$

$$
A A^{-I} V_{t}=A^{-I} \beta_{i j} V_{t-i}+A^{-I} B \varepsilon_{i t}
$$

where $A A^{-I}$ is an identity matrix. Then equation 2 is written as

$$
V_{t}=\lambda_{i j} V_{t-i}+U_{i t}
$$

where $\lambda_{i j}=A^{-I} \beta_{i j}, \quad U_{i t}=A^{-I} B \varepsilon_{i t}$. The new innovation is $U_{i t}$. Unlike equation 1 , the reduced form VAR can be estimated.

The structural VAR innovations, $B \varepsilon_{i t}$ can be retrieved from the reduced VAR innovations: $U_{i t}=A^{-1} B \varepsilon_{i t}$ obtained in equation 3 .

SVAR cannot be directly estimated from equation 1 because of over-identification. For SVAR identification, the use of arbitrary restriction affects the empirical output and VAR auxiliaries whereas non-arbitrary restrictions are often preferred (Ronayne, 2011). The non-arbitrary restriction is theoretical. By imposing theoretical restrictions on either A or B matrix or both (AB-model) in equation 3, equation 4 is the identified (estimable) SVAR. To derive B-model, assume $\mathrm{A}$ is a diagonal matrix in equation 5 and impose $\frac{\left(n^{2}-n\right)}{2}$ theoretical restrictions on the B matrix which gives

$$
A U_{i t}=B \varepsilon_{i t}
$$

In this study, 6 theoretical restrictions were imposed on the B matrix in equation 5 presented in matrix form as

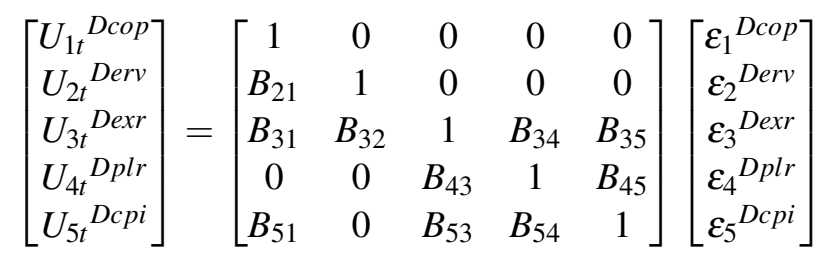

In linear form, equation 5 written as

$$
\begin{aligned}
& U_{1 t}^{\text {Dcop }}=\varepsilon_{1}{ }^{\text {Dcop }} \\
& U_{2 t}^{\text {Derv }}=B_{21} \varepsilon_{2}^{\text {Derv }}+\varepsilon_{2}{ }^{\text {Derv }}
\end{aligned}
$$




$$
\begin{aligned}
& U_{3 t^{D e x r}}=B_{31} \varepsilon_{3}{ }^{D e x r}+B_{32} \varepsilon_{3}{ }^{D e x r}+B_{34} \varepsilon_{3}{ }^{D e x r}+B_{35} \varepsilon_{3}{ }^{\text {Dexr }}+\varepsilon_{3}{ }^{D e x r} \\
& U_{4 t}{ }^{D p l r}=B_{43} \varepsilon_{4}{ }^{D p l r}+B_{45} \varepsilon_{4}{ }^{D p l r}+\varepsilon_{4}{ }^{D p l r} \\
& U_{5 t}{ }^{D c p i}=B_{51} \varepsilon_{5}^{D c p i}+B_{53} \varepsilon_{5}{ }^{D c p i}+B_{54} \varepsilon_{5}{ }^{D c p i}+\varepsilon_{5}^{D c p i}
\end{aligned}
$$

The vector, $U_{1 t}$ to $U_{5 t}$ are reduced form innovation for crude oil price (Dcop), external reserves (Derv), exchange rate (Dexr), prime lending rate (Dplr), and consumer price index (Dcpi) respectively. The vector $\varepsilon_{1}$ to $\varepsilon_{5}$ are SVAR innovations Dcop, Dexr, Derv, Dplr, and Dcpi, respectively.

The theoretical restriction imposed on B matrix implies, starting from the first row in equation 5, international oil price is majorly influenced by OPEC and Non OPEC members supply in the international market. Hence, this study assumes in equation 5, crude oil price is not influenced contemporaneously by all the variables in the model. This implies the study variables have no significant effect on oil price.

A significant proportion of Nigeria foreign reserve is solely from oil sales. Thus, the improvement in external reserves is contemporaneously affected by increases in crude oil price. External reserves are the backbone of managed floating exchange rate regime in Nigeria. On this backdrop, this study assumes external reserves has a contemporaneous effect on exchange rate. In addition, exchange rate responds contemporaneously to crude oil prices, interest rate and domestic price. Exchange rate and domestic price level have a contemporaneous effect on interest rate. Lastly, consumer price index is affected contemporaneously by crude oil price, exchange rate and interest.

\subsection{Model Estimation Procedure}

We begin by examining the unit root properties of the variable to see their level of stationarity using the linear and nonlinear unit root test. For the linear unit root test, Augmented Dickey Fuller test is adopted with the null hypothesis that a series has a unit root process. For the nonlinear unit root test, this study adopts Kapetanios, Shin and Snell (2003) (KSS) test. The null hypothesis is series has nonlinear unit root. If the null hypothesis is rejected, it implies the series, has a globally stationary process. Equation 4 is estimated using the var package of Pfaff (2008). The impulse response and the variance decomposition were computed. Robustness check will be conducted using NBER dating of business cycle. 


\section{Results and Discussion}

Table 1 presents the summary statistics for the variables. For crude oil price, the post crisis mean is larger than the pre-crisis oil price. The standard deviation of the post crisis crude oil price of 26.4 is larger than the pre-crisis value of 24.02. This implies higher volatility of oil price is prominent in the post crisis period despite higher mean value. Post-crisis exchange rate mean and standard deviation are larger than the pre-crisis period. The larger post crisis exchange rate mean and standard deviation imply the post crisis era was characterized by exchange rate depreciation in the midst of high volatility.

Table 1: Summary Statistics

\begin{tabular}{lllllll}
\hline & Entire & \multicolumn{3}{l}{ Pre-crisis } & \multicolumn{2}{l}{ Post-crisis } \\
\hline & Mean & St. Dev. & Mean & St. Dev. & Mean & St. Dev. \\
Lcop & 65.74 & 30.83 & 46.09 & 24.02 & 80.35 & 26.4 \\
Lexr & 193.7 & 94.04 & 133.32 & 10.87 & 247.32 & 103.15 \\
Lerv & $31,111.64$ & $14,876.13$ & $21,098.10$ & $16,257.40$ & $36,869.60$ & $6,522.33$ \\
Lcpi & 120.94 & 69.25 & 58.77 & 17.78 & 173.82 & 53.7 \\
Lplr & 18.26 & 2.84 & 19.9 & 3.01 & 17.1 & 2.01 \\
\hline
\end{tabular}

Source: Author computation

For external reserve, there is an increase in the mean and standard deviation after the crisis. The mean value for post crisis consumer price index is higher compared to pre-crisis. Hence, post crisis CPI was larger and with greater fluctuation compared to pre-crisis CPI.

The summary of ADF unit root test for the pre and post crisis era are presented in Table 2. The variables are having a unit root each at log level (l) except for interest rate for the full study period. The nonstationary variables turn stationary after taking the first difference (D). This is also true for the pre and post crisis samples except for interest rate, which is stationary at level in the post crisis period. The first difference (D) variables presented in Table 2 are all stationary at $1 \%$ significance level. By implication, the study variables are stationary at first difference (none contain I(2)). To assess if the variables have nonlinear unit root process, Kapetanios, Shin and Snell (2003) KSS test result is presented in Table 3. KSS t-statistics on demean and detrended data are less than tabulated critical values presented in Table 4. For detrended data, the entire sample and the post crisis sample results imply, exempting interest rate, the null hypothesis of a linear unit root process could not be rejected at $5 \%$ significance level. 
Table 2: Unit Root Test

\begin{tabular}{llllllll}
\hline $\begin{array}{l}\text { Level } \\
\text { var. }\end{array}$ & const & $\begin{array}{l}\text { const \& } \\
\text { inter- } \\
\text { cept }\end{array}$ & decision & & const & $\begin{array}{l}\text { const \& } \\
\text { intercept }\end{array}$ & decision \\
\hline \multicolumn{2}{l}{ Entire sample } & & & & & \\
Lcop & -1.9 & -1.91 & $\mathrm{I}(1)$ & Dcop & $-9.32^{* *}$ & $-9.32^{* *}$ & $\mathrm{I}(0)$ \\
Lcpi & -1.27 & -3.23 & $\mathrm{I}(1)$ & Dcpi & $-10.8^{* *}$ & $-10.84^{* *}$ & $\mathrm{I}(0)$ \\
Lexr & -0.46 & -1.58 & $\mathrm{I}(1)$ & Dexr & $-8.55^{* *}$ & $-8.55^{* *}$ & $\mathrm{I}(0)$ \\
Lerv & -2.12 & -1.16 & $\mathrm{I}(1)$ & Derv & $-7.34^{* *}$ & $-7.51^{* *}$ & $\mathrm{I}(0)$ \\
Lplr & $-3.04^{*}$ & $-3.98^{*}$ & $\mathrm{I}(0)$ & Dplr & $-16.45^{* *}$ & $-16.42^{* *}$ & $\mathrm{I}(0)$ \\
Pre-Crisi & & & & & & & \\
Lcop & 0.52 & -2.21 & $\mathrm{I}(1)$ & Dcop & $-7.76^{* *}$ & $-7.99^{* *}$ & $\mathrm{I}(0)$ \\
Lcpi & -1.38 & -2.11 & $\mathrm{I}(1)$ & Dcpi & $-7.05^{* *}$ & $-7.12^{* *}$ & $\mathrm{I}(0)$ \\
Lexr & -2.43 & -1.99 & $\mathrm{I}(1)$ & Dexr & $-5.2^{* *}$ & $-6.03^{* *}$ & $\mathrm{I}(0)$ \\
Lerv & 0.6 & -1.06 & $\mathrm{I}(1)$ & Derv & $-5.34^{* *}$ & $-5.43^{* *}$ & $\mathrm{I}(0)$ \\
Lplr & -0.06 & -2.22 & $\mathrm{I}(1)$ & Dplr & $-6.77^{* *}$ & $-6.85^{* *}$ & $\mathrm{I}(0)$ \\
Post Crisis & & & & & & \\
Lcop & -1.42 & -1.85 & $\mathrm{I}(1)$ & Dcop & $-6.83^{* *}$ & $-6.8^{* *}$ & $\mathrm{I}(0)$ \\
Lcpi & -0.5 & -1.48 & $\mathrm{I}(1)$ & Dcpi & $-5.85^{* *}$ & $-5.83^{* *}$ & $\mathrm{I}(0)$ \\
Lexr & -0.48 & -1.73 & $\mathrm{I}(1)$ & Dexr & $-6.41^{* *}$ & $-6.4^{* *}$ & $\mathrm{I}(0)$ \\
Lerv & -1.67 & -1.66 & $\mathrm{I}(1)$ & Derv & $-5.62^{* *}$ & $-5.6^{* *}$ & $\mathrm{I}(0)$ \\
Lplr & $-5.78^{* *}$ & $-5.76^{* *}$ & $\mathrm{I}(0)$ & Dplr & $-12.8^{* *}$ & $-12.75^{* *}$ & $\mathrm{I}(0)$ \\
\hline
\end{tabular}

Source: Author computation using the urca package of Pfaff et al., (2016) in R. '**' and '*' represent $1 \%$ and $5 \%$ significance level.

Table 3: Nonlinear Unit Root Test

\begin{tabular}{lllllllll}
\hline & \multicolumn{2}{l}{ Detrended } & & \multicolumn{5}{l}{ Demeaned } \\
& $\begin{array}{l}\text { Entire } \\
\text { sample }\end{array}$ & $\begin{array}{l}\text { Pre- } \\
\text { crisis }\end{array}$ & $\begin{array}{l}\text { Post } \\
\text { crisis }\end{array}$ & $\begin{array}{l}\text { 5pct } \\
\text { Sig. }\end{array}$ & $\begin{array}{l}\text { Entire } \\
\text { sample }\end{array}$ & $\begin{array}{l}\text { Pre- } \\
\text { crisis }\end{array}$ & $\begin{array}{l}\text { Post } \\
\text { crisis }\end{array}$ & $\begin{array}{l}\text { 5pct } \\
\text { Sig. }\end{array}$ \\
\hline Lcpi & -0.81 & -0.50 & -0.41 & -3.4 & -0.93 & -1.87 & -0.34 & -2.9 \\
Lerv & -1.52 & -0.62 & -1.85 & -3.4 & -2.10 & 0.14 & -1.76 & -2.9 \\
Lexr & -0.87 & -1.40 & -0.14 & -3.4 & -1.35 & -2.02 & -1.60 & -2.9 \\
Lcop & -1.94 & -1.19 & -0.98 & -3.4 & -2.16 & 1.25 & -2.07 & -2.9 \\
Lplr & -7.89 & -1.38 & -5.15 & -3.4 & -5.77 & -1.08 & -5.15 & -2.9 \\
\hline
\end{tabular}

Source: Author computation.

For further check, all the series were detrended and the results have a linear stationary process for the entire sample, pre-crisis and post crisis periods with the exception of interest rate which is nonlinear for entire and post crisis period. The detrended and demeaned variables in Table 3 choice of augmentation term are attained by augmenting the lag up to point when additional increase yielded an insignificant p-value. Then, the choice of lag that is significant 
is adopted. Having ascertained that none of the variable is I (2) and that the ADF test is linearly informative, we then move to adopt the variable to estimate the SVAR model.

Table 4: Asymptotic critical values of KSS statistic

\begin{tabular}{llll}
\hline Fractile(\%) & Raw data & De-meaned & De-trended \\
\hline 1 & -2.82 & -3.48 & -3.93 \\
5 & -2.22 & -2.93 & -3.4 \\
10 & -1.92 & -2.66 & -3.13 \\
\hline
\end{tabular}

Note: 1,5 and 20 are 99, 95 and 90 percent confidence level Source: Kapetanios et al. (2003), pg. 364

\subsection{Impulse Response of One Standard Deviation Shock to Crude Oil Price}

Figure 5 shows the impulse response function (IRF) graphs. The dotted lines are $95 \%$ bootstrap Confidence bands. For sensitivity check, the study adopts a non-arbitrary approach of the NBER definition of the crisis period from 2008M01 to 2009M06.

Figure 5 presents the response of consumer price index to shock on crude oil price over a nine-month period. A positive shock on crude oil price leads to an instantaneous increase in pre-crisis CPI. The shock dies out fast starting from the second month. Adekoya and Adebiyi (2020) study for Economic Co-operation and Development (OECD) countries observed precrisis oil price - inflation relation to be greatly affected by oil price. Pre-crisis consumer price index responds temporarily to shock in crude oil price. The direct effect of inflation was observed by Živkov, Đurašković and Slavica Manić (2019) for some selected countries in CEECs. The response of the post crisis CPI is positive in the first period. The post crisis CPI jolted upward for second month after the shock on oil price must have resonated on the economy and then stabilized around 0.01. One prominent feature of the post crisis era is the pressure for complete removal accompanied by gradual removal of fuel subsidy generated domestic price instability. This could probably explain the positive jump in post crisis CPI given positive shock on post crisis oil price.

Figure 6 presents the response of consumer price index to shock on exchange rate. Pre-crisis consumer price index is instantaneously impacted positively with a fast decline in the first period and then stabilize in the second period before converging towards zero. The post crisis CPI response is almost similar to pre-crisis CPI response except for a sharp jolt in post crisis CPI for the second to third period then it stabilized around 0.17. Positive shock on exchange rate has persistent inflationary pressure on post crisis CPI. This persistence does 
not exist for the pre-crisis CPI. Figure 7 presents the response of consumer price index for an impulse on pre and post crisis interest rate. Domestic price response to shock on pre-crisis interest rate is very steep and transitory and the response for post crisis jolted upward from second period and then fluctuates around 0.12 .
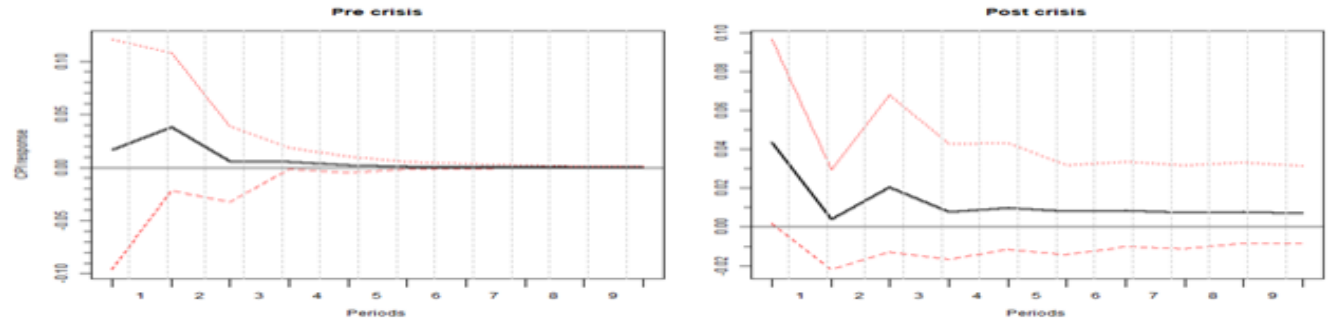

Figure 5: CPI responses to Impulse on Crude oil price
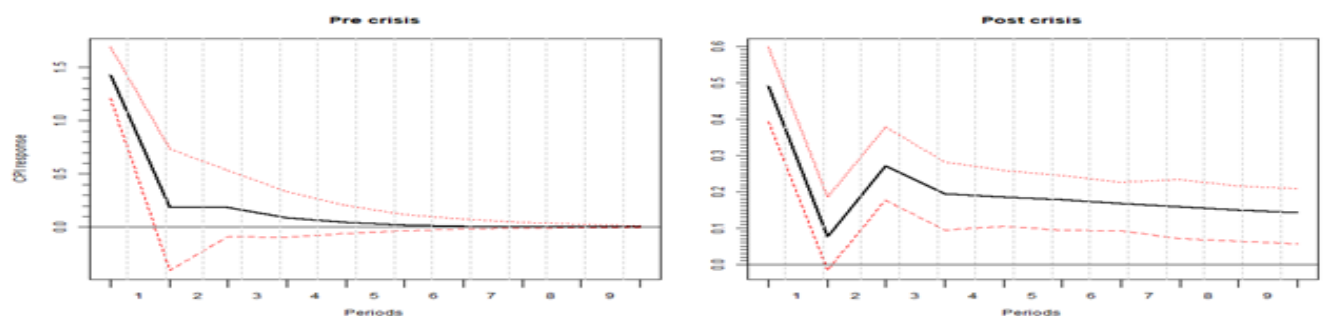

Figure 6: CPI responses to Impulse on exchange rate
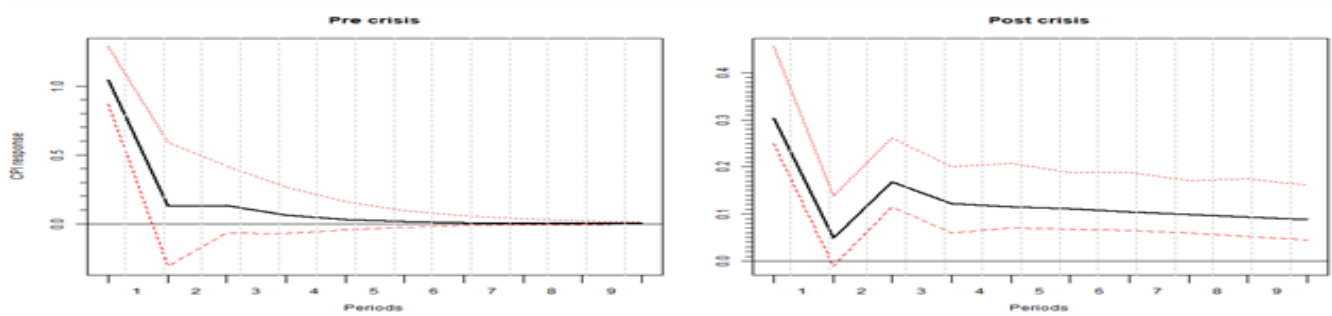

Figure 7: CPI responses to Impulse on interest rate

The response of CPI to shock on exchange rate and interest rate appears similar in pattern but different response. For pre-crisis CPI, the first and the second month shows large confidence interval bands which portrays a weak evidence for consumer price steadiness. This is true, due to import dependent nature of the economy.

Figures 8, 9 and 10 present the response of exchange rate to shocks on selected variables. From Figure 8, the response of exchange rate for shock on crude oil price varies in the two eras. From onset, post crisis oil price shocks created appreciating effect, then followed 
by depreciation of exchange rate before dissipating in the third month onward. The large confidence bands imply the depreciation in the first and second month is likely not to happen. In other words, the phenomenon of Dutch disease syndrome is transitory in the post crisis era.
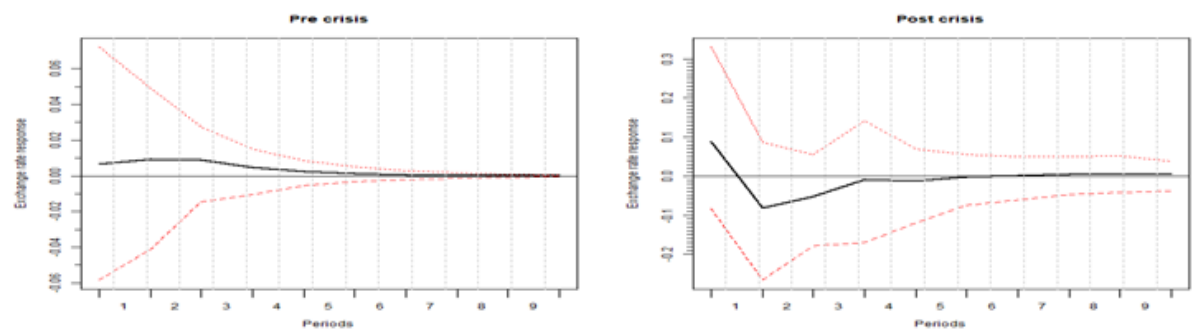

Figure 8: Response of Exchange rate to Impulse on Crude oil price
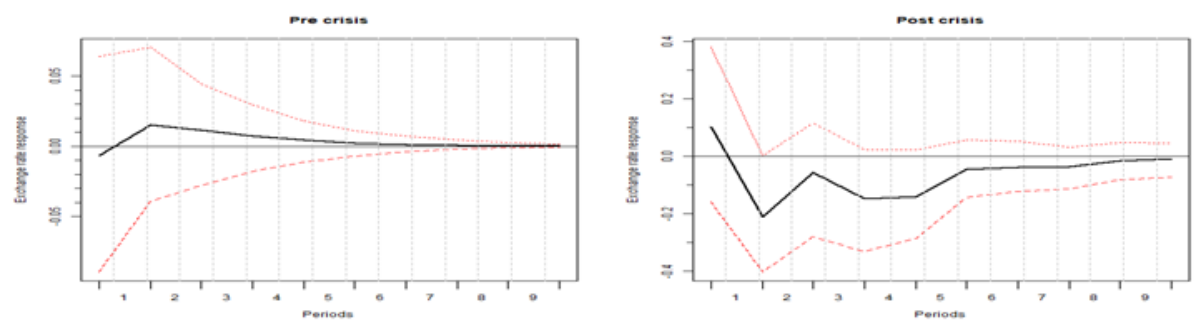

Figure 9: Response of Exchange rate to Impulse on External reserve
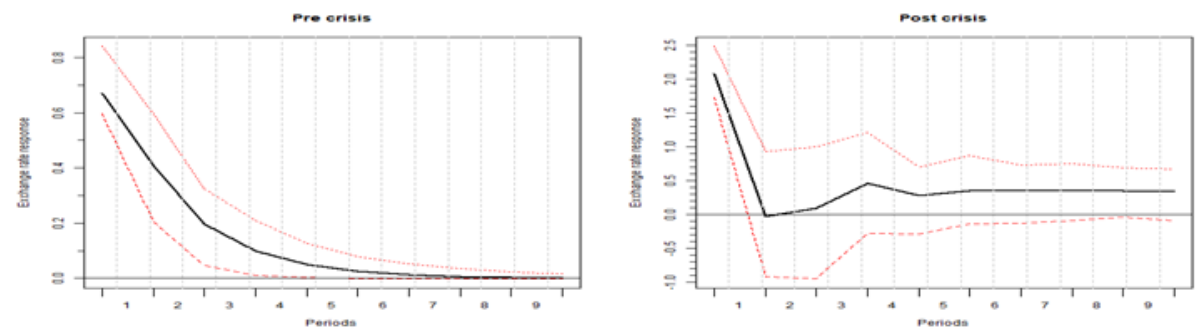

Figure 10: Response of Exchange rate to Impulse on Consumer price index

Similarly, in Figure 9 exchange rate response does vary across the eras. The depreciation of exchange rate in the pre-crisis era is statistically insignificant whereas, the appreciation experienced in the post crisis era is more likely to occur and span longer periods. A good example is the $\mathrm{CBN}$ foreign exchange restriction which has helped stem the sharp depletion of foreign reserve that usually accompanies oil price decline. By stemming the depletion of reserve, CBN tends to have much control in defending the Naira in the foreign exchange market. 
Lastly, Figure 10 shows shock on consumer price index causes exchange rate depreciation in both eras. The post crisis shock on CPI rebounds in the third month after being insignificant in the first and second month. Increase in domestic prices serves as investment incentives for investors and importers. Consumer price index is essential to investors' investment modelling. It plays a critical role in deciding where and when to invest or disinvest. Higher domestic prices incentivise investors to invest and importers to import more thereby creating pressure on the value of Naira in the foreign exchange market.

On sensitivity analysis, the NBER recession approach in sub setting the sample presented in the appendix has a slight different pattern for the post crisis era compared with the arbitrary approach presented above. In the pre-crisis period, the robustness check is consistent with the arbitrary approach having same responses derived for the pre-crisis CPI. For the post crisis CPI response, the impulse response on oil price pass-through are sensitive to sample adjustment in the post crisis era. This pose a great concern on establishing a nexus for oil price pass-through to consumer price index and exchange rate.

Table 5: Consumer Price Variance Decomposition

\begin{tabular}{lllllllllll}
\hline \multicolumn{1}{c}{ Consumer price index variance decomposition } \\
\multicolumn{8}{c}{ Pre-crisis } \\
\hline Period & Dcop & Derv & Dexr & Dplr & Dcpi & Dcop & Derv & Dexr & Dplr & Dcpi \\
\hline 2 & 1.08 & 0.19 & 2.52 & 4.40 & 91.82 & 0.32 & 1.14 & 0.73 & 0.47 & 97.34 \\
4 & 1.08 & 0.34 & 3.02 & 4.45 & 91.11 & 0.71 & 2.25 & 2.99 & 0.41 & 93.64 \\
6 & 1.08 & 0.35 & 3.05 & 4.45 & 91.07 & 1.07 & 2.10 & 4.32 & 0.53 & 91.98 \\
8 & 1.08 & 0.35 & 3.05 & 4.45 & 91.07 & 1.31 & 1.96 & 4.66 & 0.54 & 91.54 \\
10 & 1.08 & 0.35 & 3.05 & 4.45 & 91.07 & 1.43 & 1.88 & 4.88 & 0.56 & 91.25 \\
12 & 1.08 & 0.35 & 3.05 & 4.45 & 91.07 & 1.54 & 1.82 & 5.04 & 0.57 & 91.04 \\
\hline
\end{tabular}

Source: Author estimation using vars package in $R$.

Consumer price index variation in the pre-crisis period is greatly affected by variation in its own lags. Interest rate and exchange rate have greater impact on the variation compared to crude oil price and external reserves in the pre-crisis period. The pre-crisis CPI are supported by Omotosho (2019) DSGE model which shows oil price shock has no substantial impact on domestic price level owing to presence of fuel subsidy in Nigeria. During the post crisis era, crude oil price explained 1.54 percent of the variation in consumer price compared to 1.08 percent during the pre-crisis era. This increment can be explained by the removal of fuel subsidy with the introduction of modulation framework. Exchange rate contributory role 
after the crisis consistently increased starting with 0.73 percent. The Post crisis exchange rate has long-lasting and increasing contributory role on domestic price fluctuations and crude oil price played very little role in domestic price variation. A similar assertion on exchange rate influencing inflation variation has been observed by Pham (2019); Rodríguez and Perrotini (2018). Pre-crisis interest rate also shows a weakened, though, marginally increasing impact on the price level. This study finding on crude oil price role in domestic price variability was similarly observed by Brini et al. (2016).

Exchange rate variation in the pre-crisis period is greatly affected by variation in its own innovation. Adenuga et al. (2012) made similar findings. The adopted variables contributed a very small variation of exchange rate. The highest proportion was from consumer price index and then external reserves. The post crisis era, external reserves and crude oil price explained a sizeable proportion in percentage of 7.12 and 6.08 in the tenth period compared to 4.70 and 3.80 percent at the first month. External reserve and crude oil price are the major channels that explain variation in exchange rate after the crisis. Similar assertion on crude oil price influencing exchange rate variation was made by Omolade et al. (2019).

Table 6: Exchange Rate Variance Decomposition

\begin{tabular}{lllllllllll}
\hline \multicolumn{1}{c}{ Exchange rate variance decomposition } \\
\multicolumn{10}{l}{ Pre-crisis } \\
\hline Period & Dcop & Derv & Dexr & Dplr & Dcpi & Dcop & Derv & Dexr & Dplr & Dcpi \\
2 & 0.09 & 0.43 & 98.06 & 0.39 & 1.04 & 3.80 & 4.70 & 90.54 & 0.19 & 0.77 \\
4 & 0.17 & 0.53 & 97.61 & 0.38 & 1.31 & 5.59 & 5.99 & 86.76 & 0.22 & 1.45 \\
6 & 0.18 & 0.55 & 97.55 & 0.38 & 1.34 & 5.99 & 7.12 & 84.42 & 0.21 & 2.27 \\
8 & 0.18 & 0.55 & 97.54 & 0.38 & 1.35 & 6.05 & 7.16 & 83.49 & 0.25 & 3.05 \\
10 & 0.18 & 0.55 & 97.54 & 0.38 & 1.35 & 6.08 & 7.12 & 82.97 & 0.25 & 3.59 \\
12 & 0.18 & 0.55 & 97.54 & 0.38 & 1.35 & 6.08 & 7.08 & 82.54 & 0.27 & 4.03 \\
\hline
\end{tabular}

\section{Conclusion and Policy Recommendations}

The study adopts an arbitrary and non-arbitrary approach in sub-setting the study sample for assessing the dynamics of oil price and inflation pass-through pre and post 2008 global crisis in Nigeria. In both eras, oil price shocks have positive impact on CPI except that the post crisis CPI response tends to be stable and long lasting starting from the third period. The confidence bands for the post crisis CPI are large indicating the long lasting positive response in CPI may pose no significant threat to price stability in the long run. By implication post crisis oil price did not pose significant threats to post crisis CPI. The intensity of the CPI response 
to shocks on exchange rate shock vary across the two eras in terms of level of significance. Prior to the GFC, the positive impact of oil price shock often tapper off immediately despite having a slight rebound on CPI - though insignificant. The post crisis CPI shows same positive response that is significant and last long. By implication price stability in the post crisis era is affected significantly by exchange rate movement after the crisis. The CBN should sustain foreign exchange restriction giving its efficacy in steming increasing volatility of exchange rate and depletion of external reserve. For Shock to interest rate, in terms of impact, both eras show positive response in CPI. The degree of the intensity vary since the post crisis CPI response tends to be long lasting and never dissipate like the pre-crisis era.

Exchange rate response to oil price shocks varies across the two era. Exchange rate depreciated in the pre-crisis era and mixed appreciation and depreciation in the post crisis era. This implies mixed support for the Dutch disease syndrome after the GFC. Exchange rate response to external reserves shock does vary across pre and post crisis periods. Exchange depreciation in the pre-crisis era is statistically insignificant whereas, the appreciation experienced in the post crisis era is more likely to occur and last for some periods. This implies a greater reliance on oil price which contributed more than 80 percent of external reserve accretion is detrimental to the competitiveness of the economy after the GFC. For shocks to CPI, exchange rate responses do not vary significantly across the two eras. The highlight from the responses is the inconsistency in the degree of appreciation which marred the post crisis era. Post crisis exchange rate depreciated and do not tapper off unlike the pre-crisis response which dies off completely in the long horizon. This implies exchange rate has become more responsive to CPI shocks in the post crisis era.

Exchange rate outperformed other variables in explaining inflation variation in post crisis period. It was also observed from the variance decomposition (VDC) that external reserve and crude oil price are the major channels that explain variation in exchange rate after the crisis. At the aftermath of any crisis, government should not fully deregulate energy prices and the monetary authority should sustain the current policy of foreign exchange restriction in midst of falling oil price and decreasing reserve.

Lastly, the pre and post GFC analysis of oil price shocks role on CPI has shown that the pass-through of oil price to CPI does vary in terms of level of significance and persistence. Hence, external shocks are major source of structural breaks in any export-import dependent 
economy which can create misleading inferences in establishing oil price pass-through to CPI when not accounted for. This study has shown that 2008 GFC is a major source of structural instabilities that should be considered in examining the impact of oil price on the Nigeria economy. From the CPI response to oil price shock, the robustness checks show that findings from the arbitrary approach in defining the crisis did not differ significantly from the NBER definition of the crisis particulaly in the pre-crisis period definition. By implication, either the NBER approach or the arbitrary approach could be adopted in establishing oil price pass-through to inflation.

\section{References}

Abubakar, A. B. (2019). Oil price and exchange rate nexus in Nigeria: Are there asymmetries. CBN Journal of Applied Statistics, 10 (1), 1-28.

Adenuga, O. A., Hilili, J. M., \& Evbuomwan., O. O. (2012). Oil price pass-through into inflation: empirical evidence from Nigeria. Economic and Financial Review, 50(1),121.

Adekoya, O. B. \& Adebiyi, A. N. (2020). Oil price-inflation pass-through in OECD countries: The role of asymmetries, impact of global financial crisis and forecast evaluation. International Journal of Energy Sector Management, 14(1), pp. 126-147. https://doi.org/10.1108/IJESM-02-2019-0013.

Akamobi, O. G., \& Ugwunna, O. T. (2017). Determinants of foreign reserve in Nigeria. Journal of Economics and Sustainable Development, 8 (20), 58-67.

Akinleye, S. O., \& Ekpo, S. (2013). Oil price shocks and macroeconomic performance in Nigeria. Conomía Mexicana Nueva Época, 2, 565-624.

Apere, T., \& Eniekezimene, A. (2016). Crude oil price fluctuation and the Nigerian economy. International Journal of Social Science and Economic Research, 1(06), 760770 .

Asekunowo, V. O. (2016). The causes of persistent inflation in Nigeria. CBN Journal of Applied Statistics, 7(2), 49-75.

Bala, U., \& Chin, L. (2018). Asymmetric impacts of oil price on inflation: An empirical study of African OPEC. Energies, 11(3017), 1:21. https://doi.org/10.3390/en11113017

Beckmann, J., Czudaj, R., \& Arora, V. (2017). The relationship between oil prices and exchange rates: Theory and evidence. Working Paper Series (pp. 1-62). Washington, DC: U.S. Department of Energy. 
Bhattacharya, K. and Bhattacharya, I (2001). Impact of increase in oil prices on inflation and output in India, Economic and Political Weekly, 36(51), 4735-4741.

Blanchard, O. J., \& Gali, J. (2007). The macroeconomic effects of oil shocks. Why are the 2000s so different from the 1970s? National bureau of economic research, 1-78. Retrieved from http://www.nber.org/papers/w13368

Brini, R., Jemmali, H., \& Farroukh, A. (2016). Macroeconomic impacts of oil price shocks on inflation and real exchange rate: Evidence from selected MENA countries. Topics in Middle Eastern and African Economies, 18(2), 170-184.

Central Bank of Nigeria (2014). Effects of monetary policy on the real economy of Nigeria: A disaggregated analysis. Occasional Paper 54, 1-73.

Central Bank of Nigeria. (2019). Statistical Bulletin

Central Bank of Nigeria. (2020). Quarterly Statistical Bulletin

Chen, H., \& Cao, S. (2019). Exchange rate movements and fundamentals: impact of oil prices and the people's republic of china's growth. ADBI Working Paper No. 938. $1-31$

Chen, S., Ouyang, S., \& Dong, H. (2020). Oil price pass-through into consumer and producer prices with monetary policy in China: Are there non-linear and mediating effects. Frontiers Energy Research, 8(36), 1-17. https://doi.org/10.3389/fenrg.2020.00035

Choi, S., Furceri, D., Loungani, P., Mishra, S., \& Poplawski-Ribeiro, M. (2017). Oil Prices and Inflation Dynamics: Evidence from Advanced and Developing Economies IMF Working Papers 17/196, International Monetary Fund.

Demachi, K. (2012). The effect of crude oil price change and? volatility on Nigerian economy. MPRA Paper No. 41413, 1-35.

Dickey, D.A., \& Fuller, W.A. (1979). Distribution of the estimators for autoregressive time Series with a unit root. Journal of the American Statistical Association, 74(1), 427431.

Fratzscher, M. (2009). What explains global exchange rate movements during the financial crisis? In European Central Bank Working paper (No. 1060).

Gao, L., Kim, H., \& Saba, R. (2014). How do oil price shocks affect consumer prices? Energy Economics, (September), 1:24. https://doi.org/10.1016/j.eneco.2014.08.001

Hamilton J. D. (2017). Why you should never use the Hodrick-Prescott Filter. NBER Working Paper No. 23429.

Kapetanios, G., Shin, Y., \& Snell, A. (2003). Testing for a unit root in the nonlinear STAR. Journal of Econometrics, 112 (2003), 359-379. 
Pass-Through of Crude-oil Price Shocks to Consumer Prices in

Krugman, P. (1983). Oil and the dollar. In B. Jagdeeps, \& P. Bulfordh (Eds.), Economic Interdependence and flexible exchange rates. Cambridge, MA: MIT Press.

Leduc, S., \& Liu, Z. (2012). Uncertainty, unemployment, and inflation. FRBSF Economic Letter, Federal Reserve Bank of San Francisco, issue sep17.

Lee, J., \& Song, J. (2009). Nature of oil price shocks and monetary policy. National bureau of economic research, 1-36. Retrieved from http://www.nber.org/papers/w15306

Ltaifa, N. B., Kaendera, S., \& Dixit, S. V. S. (2009). Impact of the global financial crisis on exchange rates and policies in sub-Saharan Africa, IMF Departmental Papers / Policy Papers 09/06, International Monetary Fund.

Lutkepohl, H. (2008). Impulse response function. The New Palgrave Dictionary of Economics, 1-5. DOI:10.1057/978-1-349-95121-5_2410-1

Maina, G. P. (2015). Transmission Channels of crude oil price shocks on Kenya's

Melvin, M. \& Taylor, M. P., (2009). The Crisis in the foreign exchange market. CESifo Working Paper Series No. 2707.

Omolade, A., Ngalawa, H., \& Kutu, A. (2019). Crude oil price shocks and macroeconomic performance in Africa's oil-producing countries. Cogent Economics \& Finance, 7 (1607431), 1-17. Retrieved from https://doi.org/10.1080/23322039.2019.1607431

Omolade, A., Nwosa, P., \& Ngalawa, H. (2019). Monetary transmission channel, oil price shock and the manufacturing sector in nigeria. Folia Oeconomica Stetinensia, 19(1), 90:113. https://doi.org/10.2478/foli-2019-0007

Onyekwena, C., Adedeji, A., Akanonu, P. C., \& Momoh, A. (2017). Energy subsides in Nigeria: Opportunities and challenges. In Centre for the Study of the Economies of Africa (CSEA).

Olomola, P. A., \& Adejumo, A. V. (2006). Oil price shocks and macroeconomic activities in Nigeria. International Research Journal of Finance and Economics, 3, 28-34

Omotosho, B. S. (2019). Oil price shocks, fuel subsidies and macroeconomic (In) stability in Nigeria. CBN Journal of Applied Statistics, 10(2), 1-38.

https://doi.org/10.33429/Cjas.10219.1/6

Pfaff, B. (2008). VAR, SVAR and SVEC models: Implementation within R package vars. Journal of Statistical Software 27(4). URL: http://www.jstatsoft.org/v27/i04/.

Pfaff, E. Zivot, \& M. Stigler. urca: Unit Root and Cointegration Tests for Time Series Data, 2016. URL https://CRAN.R-project.org/package=urca. R package version 1.3-0 
Pham, V. A. (2019). Exchange rate pass-through into inflation in Vietnam: evidence from VAR model. Journal of Economics and Development, 21(2), 144-155. https://doi.org/10.1108/JED-07-2019-0013

R Core Team (2019). R: A language and environment for statistical computing. R Foundation for Statistical Computing, Vienna, Austria. URL https://www.R-project.org/.

Raghavan, M. (2015). The macroeconomic effects of oil price shocks on ASEAN-5 economies. Tasmanian School of Business and Economics University of Tasmania. 1-40.

Rodríguez, D., \& Perrotini, I. (2018). The impact of oil price shocks on Mexico's real exchange rate and inflation. Economía Teoría y Práctica, 4, 103-124.

Ronayne, D., (2011). Which impulse response function? Economic Research Papers 270753, University of Warwick - Department of Economics.

Sims, C. A. (1980), Macroeconomic and reality. Econometrica, 48 (1), 1-48

Tang, W., Wu, L., \& Zhang, Z. (2010). Oil price shocks and their short- and long-term effects on the Chinese economy. Energy Econ., 32, 3-14.

Trehan, B \& Zorrilla,O. (2012). The financial crisis and inflation expectations, FRBSF Economic Letter, Federal Reserve Bank of San Francisco, issue sep24.

Tufail, S. \& Qurat-ul-Ain, S., (2013). The effect of oil price shocks on the dynamic relationship between current account and exchange rate: evidence from D-8 Countries. The Pakistan Development Review, 537-555.

Usman, M. M. Nawaz, R. M. \& Qayyum, M. (2011). Impact of oil price volatility on macroeconomic variables (A case study of Pakistan). Journal of Asian Business Strategy, 1(2), 16-21.

World Bank (2019). World Bank Commodity Price Data (The Pink Sheet). Updated on April 02.

World Bank. (2019). Global Economic Prospects, January 2019: Darkening Skies. Washington, DC: World Bank. DOI: 10.1596/978-1-4648-1343-6.

Yakub, M. U., Sani, Z., Obiezue, T. O., \& Aliyu, V. O. (2019). Empirical investigation on exchange rate volatility and trade flows in Nigeria. Central Bank of Nigeria Economic and Financial Review, 57 1, 23-46.

Younas, M. Z. \& Khan, M. A. (2018). Macroeconomic impacts of external shocks on economy: recursive vector autoregressive (RVAR) Analysis. Bulletin of Business and Economics, 7(4), 169-184. 
Pass-Through of Crude-oil Price Shocks to Consumer Prices in Nigeria: Pre and Post 2008 Global Financial Crisis

Živkov, D., Đurašković, J., \& Manić, S. (2019). How do oil price changes affect inflation in Central and Eastern European countries? A wavelet-based Markov switching approach. Baltic Journal of Economics, 19(1), 84-104.

https://doi.org/10.1080/1406099X.2018.1562011

\section{Appendixes}

NBER APPROACH FOR SAMPLE SUBSETS
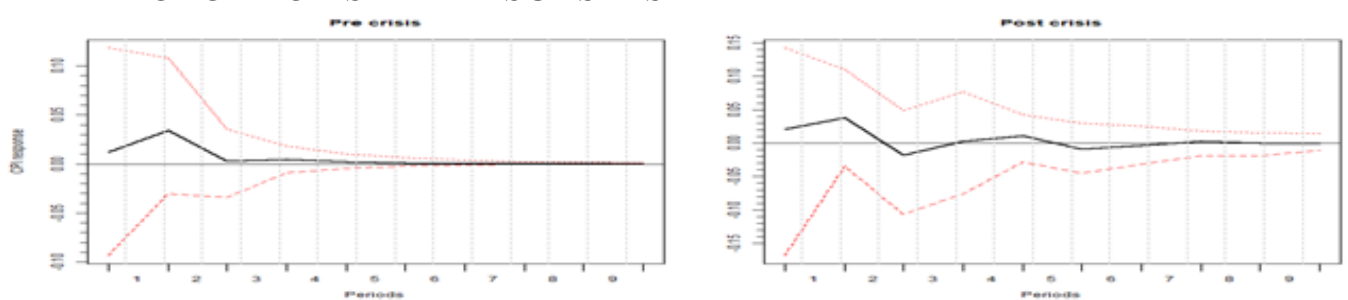

A: Impulse on oil price
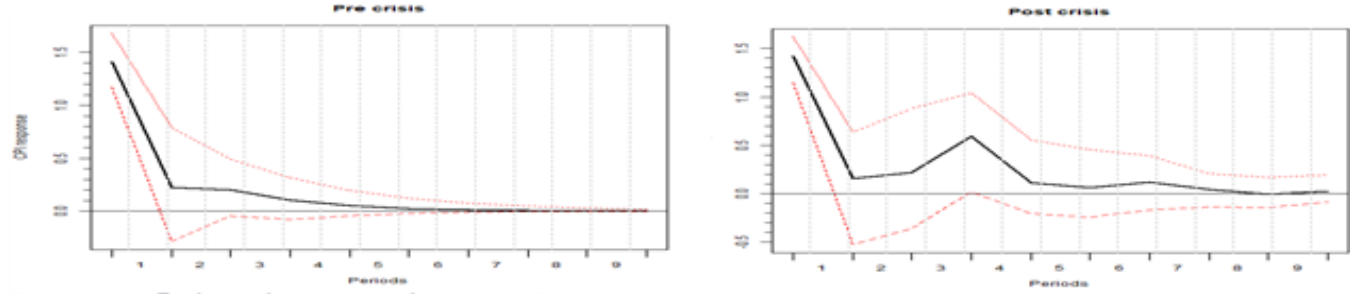

B: Impulse on exchange rate
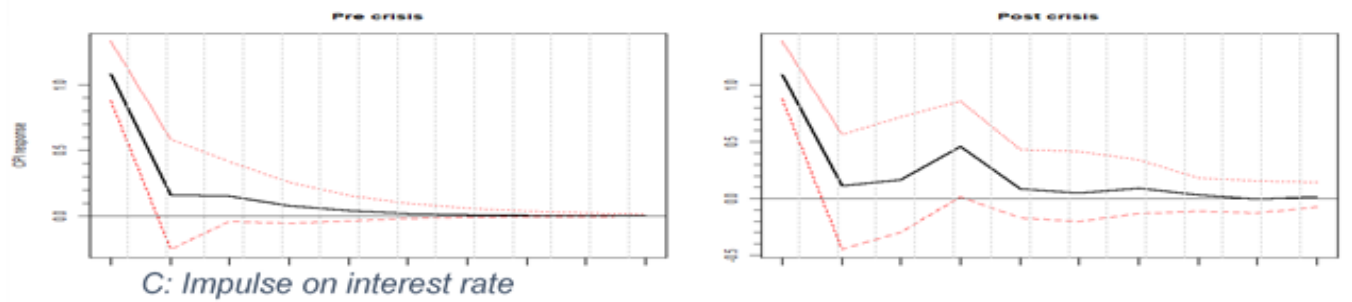

RESPONSES OF CPI 

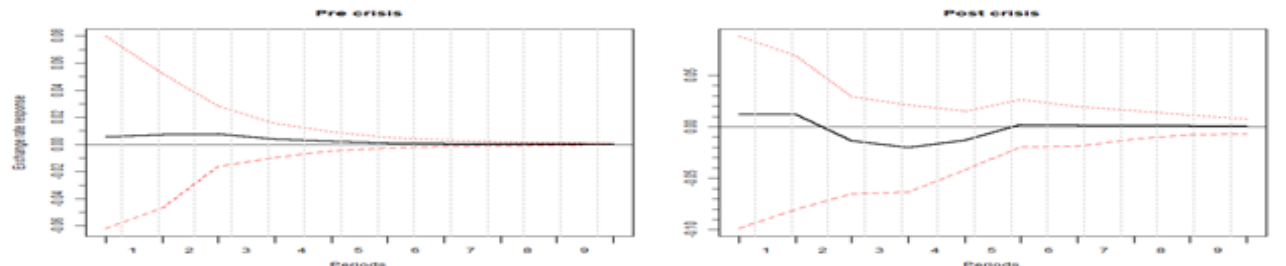

D: Impulse on oil price
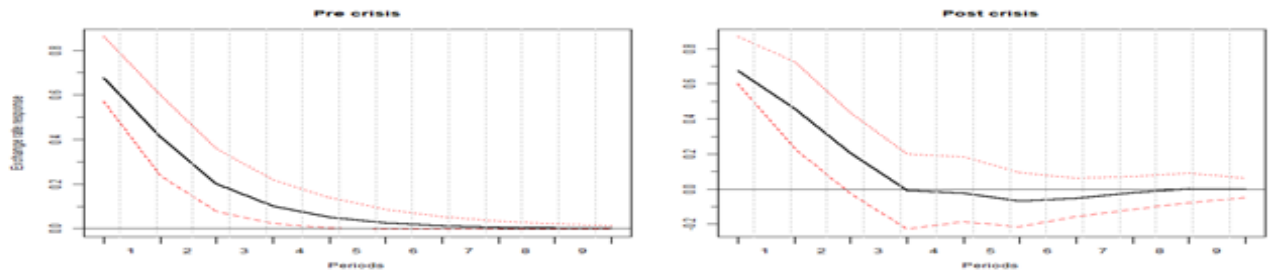

E: Impulse on consumer price index
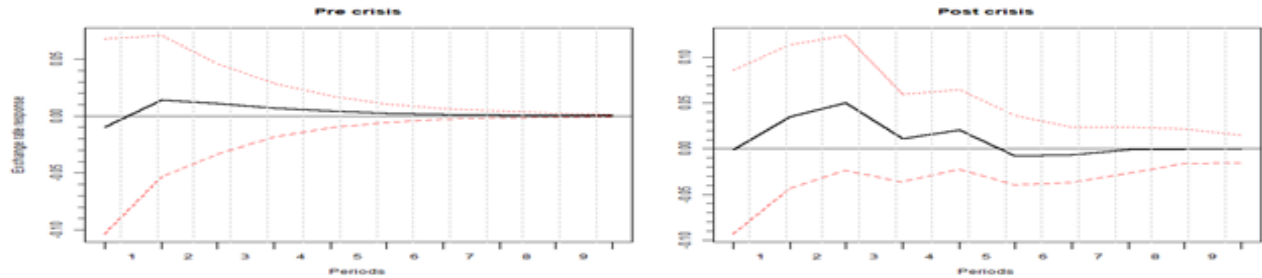

F: Impulse on external resenves

RESPONSES OF EXCHANGE RATE

\begin{tabular}{lllll}
\hline LAG LENGTH CRITERIA & & & \\
EPISODES & AIC & HQ & SC(n) & FPE(n) \\
\hline First & 1 & 1 & 1 & 1 \\
Second & 3 & 1 & 1 & 3 \\
\hline
\end{tabular}

